\title{
TATA AMARAL
}

\section{CINEASTAS}

Uma das definições de "cineasta" é "um entusiasta do cinema”. Há o complemento: "pessoa envolvida no fazer cinematográfico".

Vou adotar esta definição. Sempre gostei dela pela sua abrangência e complexidade. Tendemos a excluir da categoria "cineasta" aqueles que escrevem e/ou pensam os filmes. Para nós, o cineasta é somente aquele que dirige, monta, realiza, enfim, o filme. Quase que chegamos a excluir os produtores da categoria "cineasta".

Na definição adotada, a do entusiasta do cinema, quero incluir os teóricos e críticos. Claro! São entusiastas do cinema.

\section{OS CRÍTICOS E A PRODUÇÃO BRASILEIRA}

Aqui no Brasil desenvolvemos uma relação bastante criativa entre a crítica e o fazer cinematográfico. Há críticos que se tornam diretores, roteiristas, atores (ressalto especialmente meu grande parceiro criativo, Jean-Claude Bernardet, crítico, roteirista, diretor, ator). Há, ainda, diretores e/ou roteiristas que se debruçam a estudar teoria e a produzir reflexões e críticas.

Esta relação criativa acontece também pelo papel que os críticos desempenham no discurso sobre a obra e, consequentemente, na própria obra. Certa vez, Jean-Claude me contou que escreveu um texto sobre algum filme estrangeiro, francês talvez. Acho que isto aconteceu na época das reuniões da Sociedade Amigos da Cinemateca, no início dos anos 60. Ele se deu conta de que o autor do filme nunca iria ler seu texto e que suas reflexões não fariam a menor diferença na sua produção, no seu trabalho, nas suas obras futuras. Segundo me lembro. Foi então que Jean-Claude decidiu debruçar-se exclusivamente sobre os filmes brasileiros: ele queria intervir, provocar, fazer diferença na produção 
cinematográfica através de suas reflexões.

\section{A CRÍTICA E O FILME HOJE}

Eu gosto bastante de ouvir as reflexões que outras pessoas fazem e gosto de conversar sobre o que eu faço. Não sei se pela convivência com JeanClaude, que está sempre pensando, refletindo, provocando e tem sempre um ponto de vista original sobre as obras e seus processos, talvez porque eu goste das trocas também.

Uma das poucas visitas ao nosso (apertado) set de filmagem foi a de Luz Carlos Merten. Ele esteve presente na filmagem de uma das cenas finais e... soube do desenlace, quase antes mesmo de saber da história do filme. Foi muito discreto quanto a isto e, em seu texto, contornou lindamente o segredo. Porém, o que quero ressaltar foi a experiência com a entrevista para o jornalista: suas perguntas provocaram as primeiras verbalizações sobre o que estávamos fazendo. Foi para Merten que, pela primeira vez, falei do não-realismo com que é tratado o espaço e o tempo no filme, e de como Hoje é extremamente pessoal sem ser realmente minha história. Era a primeira vez que expressava a subjetividade do filme para alguém que não era da equipe, mas que iria comunicar o que estávamos fazendo.

Meses depois, estreamos no Festival de Brasília e, novamente, encontramos ouvidos atentos, receptivos, curiosos em relação ao nosso trabalho, por parte dos jornalistas e críticos presentes. Memorável para nós foi a relação do crítico Luiz Zanin Oricchio com o filme, que apontou Denise Fraga como atriz dramática e publicou uma interessante matéria sobre seu trabalho no filme: como a atriz se preparou para o papel, como foi a relação criativa comigo, a dinâmica de trabalho com a equipe, como acontece seu processo criativo etc. Denise foi consagrada melhor atriz pelo festival e, posso dizer, Zanin foi o primeiro a atuar iluminando-o. Foi também um dos primeiros a ressaltar aspectos narrativos estruturantes do filme: a importância do apartamento como o espaço confinado que se transforma constante e lentamente, e vai permitindo à Vera acessar seu passado a partir do presente sem o uso do dispositivo do flash back, pois ele não seria suficiente para a narrativa que buscamos construir. Este, digamos, é um dos aspectos mais importantes da construção narrativa do filme. Estes aspectos narrativos são complexos e 
compreendê-los e refletir sobre eles é um trabalho criativo de envergadura.

Mais tarde, durante o lançamento de Hoje fui agradavelmente surpreendida com a notável receptividade do filme pela crítica. A repercussão de Hoje na mídia foi enorme e inédita! A surpresa vem do fato de que o mercado de cinema está saturado de novas estreias, o que torna o espaço nos veículos de comunicação reduzido. Este espaço não é disputado apenas pelos lançamentos cinematográficos mas por toda a produção cultural que acontece hoje no Brasil.

Nosso filme foi amplamente noticiado em todos os veículos de comunicação: televisões, jornais, revistas, blogs, sites, incluindo uma capa generosíssima no Caderno 2, o caderno de cultura de $O$ Estado de S.Paulo, no dia de seu lançamento.

A ampla e positiva repercussão do filme junto à crítica alcançou a televisão, que lhe dedicou também generosos espaços.

O clipping de Hoje está reunido em quatro grandes pastas que guardamos com muito orgulho e amor. Tão significativa quanto a presença massiva do filme nos veículos de comunicação foi a qualidade dos textos produzidos sobre ele.

Hoje não foi apenas notícia. Ele provocou reflexões. Produziram-se pensamentos, construíram-se ideias a partir dele. Serei bastante injusta, a partir de agora, pois gostaria de citar nominalmente cada reflexão feita e o que provocaram. Isto será impossível.

Gostaria de apontar alguns dos aspectos do filme iluminados pela crítica, a relação com o passado: como já disse, todo o filme se passa dentro de um apartamento para onde Vera se muda, graças a uma indenização que recebe do estado brasileiro pelo desaparecimento do marido. No dia em que ela se muda, o marido volta e eles têm um encontro de amor/acerto de contas. O tempo e o espaço se condensam nesta situação. Vera faz um mergulho no passado. Para alguns críticos, o filme problematiza o esquecimento, para outros, como o crítico Carlos 
Alberto Mattos, o filme fala da solução de um trauma. Ambas as visões discutem a necessidade de refletirmos sobre nossa relação com o passado recente e os traumas da ditadura militar.

Outra reflexão sobre o uso do tempo no filme veio do crítico José Geraldo Couto, que o define como híbrido: a história acontece na intersecção (José Geraldo usa a expressão “interpenetração”) entre presente e passado. O crítico reflete sobre a paródia e sobre formas dramáticas de expressar uma relação com o passado, e a relação com a sociedade brasileira hoje. Cassio Starling Carlos ilumina o desenrolar da narrativa e a relação da personagem com a perda num texto bastante tocante. Daniel Schenker, Rodrigo Fonseca, Orlando Margarido, Sergio Rizzo, para citar alguns, refletem sobre os dispositivos narrativos e a relação do filme com o momento presente. A Revista da Cultura destaca Hoje como um fato de transformação criativa e apresenta uma grande entrevista com Denise e eu. A Revista Veja, em seu site, publica uma entrevista comigo cuja manchete é "Tata Amaral: No Brasil aceitamos a violação dos direitos humanos". O filósofo e ensaísta Peter Pal Perbert me escreve: ... "adorei, o tempo, a respiração, a delicadeza, um cinema que não explora violência alguma, mas a revela da maneira mais tocante salve o cinema!".

A crítica se debruçou sobre nosso filme abordando aspectos formais, estruturais e sua relação com o presente, com a realidade brasileira, $o$ momento atual. Estas reflexões, matérias, reportagens foram produzidas por pessoas "entusiastas do cinema”, empenhadas em produzir pensamentos e relações criativas com a obra.

\section{OS CRÍTICOS SÃO CINEASTAS}

Creio que o crítico de cinema é um cineasta e atende, portanto, à definição da pessoa "entusiasta do cinema".

Quanto à segunda parte da definição, “a pessoa envolvida no fazer cinematográfico"? Continuo incluindo os teóricos e críticos. Um filme não acontece por si só. Na hipótese de um filme ser realizado e imediatamente guardado, ele faria pouca diferença no mundo. Faria diferença para as pessoas envolvidas no seu fazer, mas seu potencial é 
muito maior quando é exibido e encontra seu público. Um filme acontece quando provoca, quando repercute, quando adquire subjetividade. Esta subjetividade, um filme adquire através dos diversos pensamentos sobre ele. Quem mais pensa sobre um filme, depois do diretor, produtor, equipe, é o crítico. No meu entender, o teórico ou crítico são também "pessoas envolvidas no fazer cinematográfico" na medida em que estão discutindo ideias, iluminando obras e seus aspectos, construindo subjetividade. Este é um processo criativo. Eles estão fazendo filmes.

Tata amaral é cineasta. Dirigiu curtas e longa-metragens como Um céu de estrelas (1997), Antônia (2006), Hoje (2011). Publicou o livro Hollywood: Depois do Terreno Baldio (O Nome da Rosa, 2007). 